\title{
Histone H2A Type 2-A
}

National Cancer Institute

\section{Source}

National Cancer Institute. Histone H2A Type 2-A. NCI Thesaurus. Code C162967.

Histone H2A type 2-A (130 aa, $14 \mathrm{kDa}$ ) is encoded by the human H2AC18 and H2AC19 genes. This protein plays a role in the modulation of chromatin compaction. 